\title{
บusisersaly
}

\section{Peacebuilding, the Rule of Law and the Duty to Prosecute: What Role Remains for Amnesties?}

Mallinder, L. (2012). Peacebuilding, the Rule of Law and the Duty to Prosecute: What Role Remains for Amnesties? In F. Medjouba (Ed.), Building Peace in Post-Conflict Situations (pp. 9-42). British Institute of International and Comparative Law.

Link to publication record in Ulster University Research Portal

\section{Published in:}

Building Peace in Post-Conflict Situations

Publication Status:

Published (in print/issue): 06/01/2012

\section{Document Version}

Author Accepted version

\section{General rights}

Copyright for the publications made accessible via Ulster University's Research Portal is retained by the author(s) and / or other copyright owners and it is a condition of accessing these publications that users recognise and abide by the legal requirements associated with these rights.

\section{Take down policy}

The Research Portal is Ulster University's institutional repository that provides access to Ulster's research outputs. Every effort has been made to ensure that content in the Research Portal does not infringe any person's rights, or applicable UK laws. If you discover content in the Research Portal that you believe breaches copyright or violates any law, please contact pure-support@ulster.ac.uk. 


\title{
PEACEBUILDING, THE RULE OF LAW AND THE DUTY TO PROSECUTE: WHAT ROLE REMAINS FOR AMNESTIES?
}

\author{
Louise Mallinder ${ }^{1}$
}

\section{INTRODUCTION}

Although the concepts of peacebuilding, transitional justice and reconciliation each share the common goal of seeking to identify how war-torn societies can transition towards lasting peace, they have distinct origins, mechanisms and rationales. As a result, from the 1990s, amnesty laws to shield offenders from legal sanctions have been at the epicentre of clashes between these different approaches. For example, the growth of transitional justice was strongly influenced by international human rights law and international legal scholars and jurists. $^{2}$ This meant that transitional justice programmes were often highly legalistic and aimed as far as possible to deliver prosecutions for serious violations of international human rights and humanitarian law. This contrasted with peacebuilding or conflict resolution strategies that sought to develop bespoke, more political solutions to tackle the problems faced by war-torn States, or with reconciliation programmes that for well-intentioned or nefarious reasons often emphasised the importance of forgiving and forgetting in rebuilding post-conflict States through the use of amnesty laws or other leniency measures. However, in recent years, the development of an international consensus on the importance of (re)establishing the rule of law in post-conflict States has contributed to a growing convergence between the concepts of peacebuilding, transitional justice and reconciliation on the permissibility of amnesty laws. As a result, contemporary amnesty laws are often the most contentious aspect of peacebuilding and reconciliation programmes. This controversy has been recognized in the EU-sponsored project on Armed Conflicts, Peacekeeping, Transitional Justice: Law as Solution (ATLAS), which has produced this edited collection. In its aims and goals, this project is required inter alia to '[d]etermine how amnesties, impunities and criminal justice contribute to post-conflict national reconciliation' and to '[a]nalyse if they are antagonistic or if they can be reconciled in a manner that satisfies the requirements of international human rights law and the rule of law, ${ }^{3}$ This paper will focus on the latter of these questions.

This analysis will begin by exploring the scope and effects of amnesty laws in order to highlight the considerable diversity among contemporary amnesties. This discussion will provide the basis for the arguments in this paper that limited, individualised and conditional forms of amnesty do not automatically result in impunity, but instead can potentially impact positively upon national reconciliation and the rule of law in post-conflict States. The following section will focus on the ambiguous concept of the rule of law by highlighting its core elements and exploring why it has such appeal for post-conflict States and international actors. The chapter will then address the relationship between amnesty programmes and the elements of the rule of law with which they most frequently conflict, namely adhering to

\footnotetext{
${ }^{1}$ Lecturer in Human Rights and International Law, Transitional Justice Institute, University of Ulster. Email: 1.mallinder@ulster.ac.uk. The author would like to thank Prof Christine Bell for commenting on an earlier draft of this paper and the participants in the 'Building Peace in Post-Conflict Situations' conference at the British Institute of International and Comparative Law on 17 February 2011 for their comments and questions.

${ }^{2}$ See eg P Arthur, 'How "Transitions" Reshaped Human Rights: A Conceptual History of Transitional Justice' (2009) 31 Hum Rts 2 Q 321.

${ }^{3}$ Based on the 'Aims and Goals' of the BIICL joint-project on Armed Conflicts, Peacekeeping, Transitional Justice: Law as Solution (ATLAS) available online at http://www.biicl.org/atlas (accessed 15 April 2011).
} 
domestic legal rules on the use of amnesty including the principles of legality and equality, enforcing international legal obligations, and ending impunity. In keeping with the ATLAS project objectives, the paper will conclude by offering some recommendations for the European Union (EU) in approaching human rights and international humanitarian law in post-conflict States.

\section{DEFINING AMNESTIES}

Amnesty laws have long been used by political leaders to promote peace and reconciliation in response to armed conflict. This history can be charted back to one of the earliest known peace agreements concluded between Rameses II of Egypt and Hatusiliš III of the Hittites in 1258 BCE. During the intervening centuries, amnesties featured in numerous peace agreements concluded following armed conflicts between States. ${ }^{4}$ Amnesties have also long been granted within States by sovereigns to subjects who breached what were then perceived as the monarch's laws. ${ }^{5}$ Such amnesties were often portrayed as acts of forgiveness or mercy emanating from the monarch towards wayward subjects, including those who had taken up arms against their ruler. ${ }^{6}$ Although the growth of transitional justice and international criminal law has caused the use of amnesty laws to become increasingly controversial, particularly from the late 1990s, amnesties continue to be frequently used in response to violent conflict. For example, according to the Amnesty Law Database compiled by the author, ${ }^{7}$ almost half of 389 amnesties laws enacted in 117 countries during the past 30 years related to conflicts, either when the conflict was still ongoing or as a result of peace negotiations. ${ }^{8}$ Similar findings have been reached by comparative large-N studies on peace agreements. Furthermore, in a survey of peace agreements made between 1980 and 2006, Vinjamuri and Boesenecker found that whilst 'provisions for prosecutions and truth commissions are rare in peace agreements ... the use of amnesty is comparatively common'. In addition, they found that the rates of amnesties in the agreements remained 'relatively stable over the time period analysed', ${ }^{10}$ even though from 2000 , the number of peace agreements concluded declined. ${ }^{11}$

Despite their long history and continued widespread use, there is a lack of conceptual clarity on the nature of amnesty laws. This arises for several reasons. Firstly, within national legal systems, the term 'amnesty' may be defined differently and different bodies may be

\footnotetext{
${ }^{4}$ See eg Nijmeguen Peace Treaty 1678, art 3, which ended the Dutch War; Utrecht Peace Treaty 1713, art 2 between France and England, concluded at the end of the Spanish Succession War; Paris Peace Treaty 1763, art 2; Tilsit Peace Treaty 1807, art 10; and Final Act of Congress of Vienna 1815, arts 11-2; Prague Peace Treaty1866, art 10; and Treaty of Constantinople 1879, art 9; and the treaties that followed World War One. For a full discussion, see F Domb, 'Treatment of War Crimes in Peace Settlements - Prosecution or Amnesty?' in Y Dinstein and M Tabory (eds), War Crimes in International Law (Martinus Nijhoff Publishers, The Hague, 1996).

${ }^{5}$ See eg K Dean Moore, Pardons: Justice, Mercy and the Public Interest (Oxford University Press, New York 1997).

${ }^{6}$ See eg R Parker, 'Fighting the Siren's Song: The Problem of Amnesty in Historical and Contemporary Perspective' (2001) 42(1/2) Acta Juridica Hungaria 69.

${ }^{7}$ This database contains information on amnesties introduced in all parts of the world since the end of the Second World War, relating to societies enduring or transitioning from violence and repression. This study, rather than sampling, includes any amnesty law that was identified and found to meet these criteria.

${ }^{8}$ The remaining amnesties enacted in this period that have been identified in the database relate to other political crisis such as dictatorial rule, military coups, and civil unrest.

${ }^{9}$ L Vinjamuri and A Boesenecker, 'Accountability and Peace Agreements: Mapping Trends from 1980 to 2006 ' (Centre for Humanitarian Dialogue, Geneva 2007) 5.

10 ibid 9.

11 ibid 13.
} 
empowered to grant amnesties. ${ }^{12}$ This can be particularly problematic where domestic law does not clearly distinguish between amnesties and pardons. ${ }^{13}$ Secondly, as amnesty laws have traditionally fallen within the domain of State sovereignty, no accepted international definition of amnesty laws has developed. As a result, the scope and effect of amnesty laws around the world can look very different, ranging from amnesty laws to provide a form of reparations to persons who have been arbitrarily detained by a repressive State to selfamnesty laws enacted by dictatorial rulers or war criminals eager to avoid penal sanctions. Indeed, Mark Freeman has suggested that 'the difference between certain amnesties is so vast... that it is almost nonsensical to compare them' ${ }^{14}$ However, in general, amnesty laws can be understood as legal tools deployed by governments to remove criminal and/or civil sanctions from specified categories of offenders or offences.

In some post-conflict contexts, distinctions between amnesties and other leniency measures, such as plea agreements or use immunity, become blurred, particularly where amnesty is offered in exchange for testimony or participation in an alternative justice process. ${ }^{15}$ Many alternative forms of leniency have similar outcomes to amnesty laws, but as yet do not attract the same international opprobrium and some such as plea bargains are an accepted part of the criminal procedures of international tribunals and some national legal systems. ${ }^{16}$

As amnesties are designed to bar to prosecutions, they are often described as being 'beyond the courts'. However, in practice their relationship to judicial institutions is much more complex. For example, where amnesty laws are proposed or enacted their legality may be challenged before constitutional courts or before international human rights monitoring bodies. Furthermore, if an amnesty is enacted, domestic courts may be involved in implementing it where they are empowered to determine if the amnesty can be applied to an individual case to foreclose prosecution or punishment. This power to determine the applicability of amnesty recognizes that often prosecutions remain possible even where amnesties are enacted. Indeed, in many amnesty processes, the possibility of prosecutions is written into the text through the limiting of amnesty to an exhaustive list of crimes or offenders, or through the exclusion of specified crimes, offenders or crimes committed outside specified dates. Alternatively, where an amnesty is conditional on individual offenders performing or refraining from specific actions, prosecutions could be pursued for those who do not fulfil the amnesties' conditions. Such limited amnesty laws are intended to complement some trials, whilst simultaneously preventing prosecutions in other cases.

\footnotetext{
${ }^{12}$ See eg R Lévy, 'Pardons and Amnesties as Policy Instruments in Contemporary France' (2007) 36 Crime \& Just 551 .

${ }^{13}$ Eg the American Constitution empowers the President 'to grant Reprieves and Pardons for Offenses against the United States, except in Cases of Impeachment' but makes no explicit reference to amnesty laws. However, in practice, this constitutional provision has been interpreted by the US Supreme Court to include the power to grant amnesties, and the Court has proclaimed that the president can exercise this power for both offenders who have been convicted and for persons who have yet to be investigated or stand trial. See U.S. Constitution, art. II, ss 2.I; United States $v$ Klein, 80 U.S. 128, 147 (1871); and Ex Parte Garland, 71 U.S. 333 (1866).

${ }^{14}$ M Freeman, Necessary Evils: Amnesties and the Search for Justice (CUP, Cambridge 2010) 13.

${ }^{15}$ For a discussion of definitions of amnesty and the distinctions between amnesty laws and other leniency measures, see ibid.

${ }^{16}$ See eg J Natalya Clark, 'Plea Bargaining at the ICTY: Guilty Pleas and Reconciliation' (2009) 20 Eur J Int'1 L 2, 415; ICTY, 'ICTY Manual on Developed Practices' (UNICRI, Turin, Italy ); N Amoury Combs, Guilty Pleas in International Criminal Law: Constructing a Restorative Justice Approach (Stanford University Press, Stanford, CA, 2007); OSCE, 'Plea Agreements in Bosnia and Herzegovina: Practices before the Courts and their Compliance with International Human Rights Standards' (OSCE, February 2006); RJ Henham and MA Drumbl, 'Plea Bargaining at the International Criminal Tribunal for the Former Yugoslavia' (2005) 16 Crim L F 1, 49; A Tieger and M Shin, 'Plea Agreements in the ICTY: Purpose, Effects and Propriety' (2005) 3 J Int'l Crim Just 666.
} 
Domestic courts can also exercise jurisdiction over amnesty processes where they are empowered to review the decisions of administrative amnesty-granting bodies. Finally, domestic courts or international or hybrid courts may face the decision whether to disregard or reinterpret pre-existing amnesty laws in light of developments in international law. This demonstrates that rather than being 'beyond the courts', amnesties are a product of the law and are often regulated by judicial mechanisms. As a result, the relationship between amnesty laws and the rule of law is a complex question that will often depend on the parameters of the amnesty and its relationship to accountability mechanisms.

\section{THE RULE OF LAW'S ALLURE IN POST-CONFLICT STATES}

As is frequently acknowledged, the rule of law is 'an exceedingly elusive notion" ${ }^{17}$ that is subject to much 'confusion ... about its meaning and scope among scholars and practitioners alike'. ${ }^{18}$ However, from ancient times, the concept has been understood as a bulwark against tyranny, as a shield of the citizen against arbitrary and unequal exercises of power by unaccountable rulers. ${ }^{19}$ Consequently, societies governed by the rule of law are places where the law is predictable and equally enforced. The exact components of the rule of law within democratic States have long been subject to scholarly debate; however, some elements are widely accepted. For example, the rule of law denotes a system in which 'laws are public knowledge, are clear in meaning, and apply to everyone'; where the 'central institutions of the legal system, including courts, prosecutors and the police, are reasonably fair, competent and efficient', and the judiciary are 'impartial and independent, not subject to political influence or manipulation', and in which the executive abides by the national laws and public servants are held accountable for their actions ${ }^{20}$ Furthermore, the rule of law requires adherence to the principles of 'supremacy of law, equality before the law, accountability to the law, fairness in the application of the law, separation of powers, participation in decisionmaking, legal certainty, avoidance of arbitrariness and procedural and legal transparency'. ${ }^{21}$

Since the 1990s, the rule of law has been seen 'as the panacea for all the problems that afflict many non-Western countries, particularly in post-conflict settings' ${ }^{22}$ The attraction of the rule of law in the aftermath of war is manifold. For example, conflicts typically corrode the rule of law through processes such as the introduction of repressive laws or the abandonment or collapse of formal legal systems. ${ }^{23}$ As a result, peacebuilding processes often entail re-establishing these damaged institutions and repealing unjust laws. Furthermore, where the law is politicised during conflicts, rebuilding it during peacetime may represent ' $a$ desire to escape from politics by imagining the rule of law as technical, legal, and apolitical'. ${ }^{24}$ This approach is based on claims that the rule of law 'speaks to values and working practices such as justice, objectivity, certainty, uniformity, universality, rationality

\footnotetext{
${ }^{17}$ BZ Tamanaha, On the Rule of Law: History, Politics, Theory (CUP, Cambridge, 2004) 9.

${ }^{18}$ R Mani, 'Conflict Resolution, Justice and the Law: Rebuilding the Rule of Law in the Aftermath of Complex Political Emergencies' (1998) 5 Int'l Peacekeeping 3, 1, 8.

${ }^{19}$ RG.Teitel, Transitional Justice (OUP, Oxford 2000) 18.

${ }^{20}$ T Carothers, 'The Rule of Law Revival' (1998) 77 Foreign Aff 2, 95, 96.

${ }^{21}$ UNSC, 'Report of the Secretary-General on The Rule of Law and Transitional Justice in Conflict and PostConflict Societies', S/2004/616 (23 August 2004) para 6.

${ }^{22}$ B Rajagopal, 'Invoking the Rule of Law in Post-conflict Rebuilding: A Critical Examination' (2008) 49 William \& Mary L Rev 4, 1347-1348.

${ }^{23}$ C Bell, C Campbell and F Ní Aoláin, 'Justice Discourses in Transition' (2004) 13 Soc \& Legal Stud 3, 305, 307.

${ }^{24}$ Rajagopal (n 22) 1349.
} 
and so on', which McEvoy argues are 'particularly prized in times of transition' ${ }^{25}$ However, as Teitel has explored, in periods of radical political change and legal instability, the rule of law is rarely politically neutral. Instead, it may serve 'to mediate the normative shift in values' in which the transitional State's legal, economic and political systems are transformed. ${ }^{26}$ In such contexts, even enforcing individual rights may represent a dramatic break from the former regime. ${ }^{27}$ Whether such dramatic changes benefit who those suffered most during the conflict will of course depend on many factors, particularly since the law has a tendency to reinforce the power of dominant social forces, usually at the expense of marginalised groups, such as women, minorities or the economically deprived. ${ }^{28}$

Where the lawlessness of conflict resulted in mass human rights abuses, the rule of law is often advocated by human rights activists as a deterrent of future abuse, through the punishment of perpetrators, the introduction of greater accountability mechanisms, and the public communication of norms and values of the respect for the rule of law. In addition, where rule of law abuses were part of the root causes of the conflict, efforts to re-establish the rule of law may help tackle these underlying structural problems and prevent the conflict's reemergence. However, as Bell notes, in fragile political transitions 'normative requirements relating to implementing the rule of law must be tempered by the political preconditions of a ceasefire necessary to implementing anything at all'. ${ }^{29}$ In other words, deviations from the rule of law, such as amnesty laws, may initially be needed in order to get to a situation where conditions permit the institutional reforms necessary to re-establish the rule of law.

Proponents of the rule of law also argue that where programmes make government officials more accountable and reform the institutions that implement and enforce the law, they have the potential 'to publicly demonstrate a newfound legitimacy and accountability'. ${ }^{30}$ This can enhance 'people's faith in state authority'. ${ }^{31}$ However, as Brooks cautions, in order to achieve this rule of law programmes must be culturally embedded, rather than externally imposed. ${ }^{32}$ Finally, for development experts and economists, the rule of law offers the potential for economic development and prosperity, which will enhance 'the long-term viability of the state'. ${ }^{33}$

Drawing on these diverse hoped-for outcomes, rule of law peacebuilding programmes today often encompass an array of measures including writing new constitutions, passing new laws, and implementing international human rights standards; reforming the judiciary, improving court facilities and training judges and lawyers; reforming and training the police and prison services; improving the transparency and accountability of government institutions; and educating the public on their legal rights and strengthening local participation in governance. ${ }^{34}$ Such rule of law programmes have gained considerable international financial backing in peacebuilding programmes around the world, and in cases

\footnotetext{
${ }^{25}$ K McEvoy, 'Beyond Legalism: Towards a Thicker Understanding of Transitional Justice' (2008) 34 J L \& Soc 4, 411, 417.

${ }^{26}$ Teitel (n 19) 11.

27 ibid 16.

${ }^{28}$ C Bell, C Campbell and F Ní Aoláin, 'Transitional Justice: (Re)conceptualising the Field' (2007) 3 Int'l J L in Context 2, 81, 83.

${ }^{29} \mathrm{C}$ Bell, On the Law of Peace: Peace Agreements and the Lex Pacificatoria (OUP, Oxford, 2008) 256.

${ }^{30}$ McEvoy (n 25) 417.

${ }^{31}$ V Gowlland-Debbas and V Pergantis, 'Rule of Law' in Vincent Chetail (ed), Post-Conflict Peacebuilding: A Lexicon (OUP, Oxford, 2009) 332.

${ }^{32}$ R Ehrenreich Brooks, 'The New Imperialism: Violence, Norms, and the Rule of Law' (2003) 101 Mich L Rev 2275.

${ }^{33}$ Gowlland-Debbas \& Vassilis Pergantis (n 31) 332.

${ }^{34}$ ibid 322.
} 
like Bosnia-Herzegovina and Kosovo, they have contributed to conditions where prosecutions of human rights violators before national courts are possible. For transitional justice activists, such prosecutions are the main goal of rule of law programmes, and consequently, where amnesties block prosecutions they are seen to represent an obstacle to the rule of law. As amnesties do not directly block wider rule of law programmes, this chapter will focus on where amnesties may potentially come into conflict with the rule of law and criminal justice, namely ensuring equality before the law, adhering to domestic legal rules on the use of amnesty, enforcing international legal obligations, and ending impunity.

This analysis is starting from the assumption articulated by the United Nations (UN) Secretary-General in his 2004 influential report on Transitional Justice and the Rule of Law in which he stated that '[i]n the end, in post-conflict countries, the vast majority of perpetrators of serious violations of human rights and international humanitarian law will never be tried, whether internationally or domestically'. ${ }^{35}$ This indicates that any post-conflict prosecution strategy will be selective, and that as a result, weighing up the merits or disadvantages of amnesty should also entail considering the impact of selective prosecutions. In particular, this analysis should consider whether the rule of law is better served by bringing those combatants or offenders who are beyond the reach of limited prosecutions into a broader peacebuilding and reconciliation programme.

\section{DOMESTIC RULES ON AMNESTY ENACTMENT}

All legal systems provide for some of leniency within their criminal justice processes, as a result, where post-conflict States wish to enact amnesty legislation, their scope for discretion may be constrained by domestic law. For example, domestic constitutions often provide rules that govern the enactment of amnesty laws. These rules can stipulate whether the executive, or legislature, or both are empowered to grant amnesty, ${ }^{36}$ which crimes amnesty can be granted for, and whether amnesty can be granted to individuals who have yet to be convicted. Furthermore, as national legislation, amnesty laws generally have comply with the normal legislative procedures. Simple adherence to such domestic rules generally represents a 'minimal rule of law, ${ }^{37}$ that is concerned with whether the law is enacted in accordance with the correct procedures, as opposed to broader ideas of the rule of law which consider whether it is morally correct to enact an amnesty law.

For an amnesty to be considered legally valid under domestic law, at a minimum, its enactment process must adhere to these formal rules. Where the formal rules are not respected, national courts may be empowered to declare the amnesty law unconstitutional. This could occur, for example, where a military government proclaims a self-amnesty in violation of domestic legal requirements that amnesties be legislated by parliament. In such cases, depending on domestic rules, the courts may declare the amnesty void or require the executive to amend the legislation so that it conforms to the appropriate standards. ${ }^{38}$

\footnotetext{
${ }^{35}$ UNSC (n 21) para 46.

${ }^{36}$ Lévy (n 12) 551

${ }^{37}$ Teitel (n 19) 58.

${ }^{38}$ Eg on 8 December 2006, responding to civil society challenges against legislation to establish a truth commission with amnesty granting powers, eight members of a nine-judge panel at the Indonesian Constitutional Court found in favour of the applicants and declared that the Law on the Truth and Reconciliation Commission had no legally binding force. The court found that Article 27, which related to the amnesty powers, entailed a 'negation of legal protection and justice, which are guaranteed under the 1945 Constitution.' It continued that as the implementation of the entire law depended on this article, the law was without force. See Constitutional Court Decision on the TRC Law, Decision Number 006/PUU-IV/2006 (Dec. 6, 2006) (Indon.).
} 
Alternatively, the government's decision may be subject to judicial review proceedings before domestic administrative courts.

Adhering to domestic legal rules on the use of amnesties might be beneficial to governments in post-conflict States, not just to avoid clashes with the judiciary, but also because it might enhance the legitimacy of an amnesty. ${ }^{39}$ This seems particularly likely where the amnesty is adopted as part of a public deliberative processes such as public consultations or national referenda. Such processes could also trigger public debate on the nature and significance of past crimes, in which the violence of the past could be repudiated and the new non-violent norms could be communicated. Such public deliberations would serve some of the expressivist goals usually ascribed to prosecutions. Indeed, Teitel argues 'the democratic provenance of many of the transitional amnesties can mean that they are frequently more transparent and deliberated over than conventional punishment' ${ }^{40}$

Finally, as noted above, enforcing the rule of law can require lawmakers and the judiciary to respect a number of key legal principles. The principles of the most relevance to amnesty laws are the principle of legality and the principle of equality.

\section{A. Principle of Legality}

The principle of legality requires that all laws should be clear, ascertainable and nonretrospective. Under this principle, a person should only be punished for actions that were criminal at the time they were perpetrated and that the offender knew them to be criminal. Due to their serious nature, this principle is not thought to apply to international crimes such as genocide, war crimes and crimes against humanity; however, arguably it may apply to other conflict-related offences. Where the rule of law was compromised during the conflict, repressive actions by State forces may be permitted under domestic law, may be encouraged through propaganda, and lower-level soldiers may be ordered to perform them by their superiors. Such actions could include a range of human rights violations that do not reach the threshold of international crimes. Where government agents committed these actions believing them to be legal, the principle of legality has been interpreted in some post-conflict States to justify granting amnesty for these crimes or excluding such actions from transitional justice processes. For example, in South Africa, the government was 'determined to demonstrate its commitment to legality and to the rule of law by avoiding any attempt to invalidate the offensive laws of apartheid retrospectively'. ${ }^{41}$ As a result, the jurisdiction of the Truth and Reconciliation Commission was tailored so that only actions that were criminal under apartheid legal system fell within the jurisdiction of the commission. ${ }^{42}$

\section{B. Equal Protection before the Law}

The principle of equal protection before the law is a core element of the rule of law and is enshrined in international human rights law. For example, the Universal Declaration of

\footnotetext{
${ }^{39}$ Teitel (n 19) 58.

${ }^{40}$ ibid 58-59.

${ }^{41}$ J Dugard, 'Retrospective Justice: International Law and the South African Model' in A. James McAdams (ed), Transitional Justice and the Rule of Law in New Democracies (University of Notre Dame, South Bend, 1997) 278-279.

${ }^{42}$ TRC Report, Vol 1, ch 4 paras 55-58; Mahmood Mamdani, 'The Truth According to the TRC' in Ifi Amadiume and Abdullahi An-Na'im (eds), The Politics of Memory: Truth, Healing and Social Justice (Zed Books, London, 2000).
} 
Human Rights (UDHR) proclaims that '[a]1l are equal before the law and are entitled without any discrimination to equal protection of the law, ${ }^{43}$ and that

[e]veryone is entitled in full equality to a fair and public hearing by an independent and impartial tribunal, in the determination of his rights and obligations and of any criminal charge against him. ${ }^{44}$

Within post-conflict States, efforts to deal with the past can come into conflict with this principle where perpetrators of similar crimes are treated differently. This problem can arise in most transitional justice processes but it is perhaps most acute in relation to limited prosecution strategies or amnesty measures. When developing these processes, legislators or prosecutors may be influenced by a number of factors including the numbers of offenders at large, the gravity of the crimes, the availability of resources, political constraints or the preexisting legal status of the offenders.

Offenders' legal status may be different for State and non-state actors as these groups are treated differently under domestic and international human rights law. Under domestic laws, members of the armed forces are treated as having a legitimate monopoly on the use of force, whereas armed opposition groups are usually prohibited under national law and are regarded by the State as criminals to be held accountable. As a result, guerrilla forces may be liable for prosecution for engaging in combat whereas State forces could be portrayed as upholding, rather than breaching the law. In addition, State forces may have already benefited from immunity measures such as indemnity laws. In addition, the legal position of State agents and non-state combatants can also be distinguished under international law as although international criminal law is viewed as applying to all participants in a conflict, ${ }^{45}$ international human rights law has traditionally been viewed as having only vertical application. This means that to protect citizens from abuses of power by their government, international human rights law restricts the actions of States, ${ }^{46}$ and that traditionally, non-state actors were not viewed as committing human rights violations. This distinction is evident in the Convention Against Torture and the Convention for the Protection of All Persons from Enforced Disappearance, as the application of both conventions is restricted to 'agents of the State or ... persons or groups of persons acting with the authorization, support or acquiescence of the State'. ${ }^{47}$ However, where such crimes occur during a conflict they could be treated as war crimes under international criminal law, which would also make non-state actors liable for prosecution. For other crimes, however, post-conflict amnesty and justice strategies may have to take into account the existence or absence of liability for different categories of offenders.

In addition to the underlying differences in the legal status of possible amnesty beneficiaries, equality issues can also arise when designing the scope of an amnesty, particularly since amnesty laws are introduced after the crimes have taken place, and thus when they occurred the perpetrators theoretically faced identical fates. For example, under the equality principle, criteria such as race, religion, class or other similar classification should not be used as a basis on which to pursue prosecutions or grant amnesty. ${ }^{48}$ Observing

\footnotetext{
${ }^{43}$ Universal Declaration of Human Rights art 7.

${ }^{44}$ ibid art 10. These rights were subsequently reiterated in arts 26 and 14(1) respectively of the International Covenant on Civil and Political Rights.

${ }^{45}$ Geneva Conventions (adopted 12 August 1949, entered into force 21 October 1950), Common art 3.

${ }^{46}$ L Zegveld, Accountability of Armed Opposition Groups in International Law (Cambridge Studies in International and Comparative Law, CUP, Cambridge 2002) 38.

${ }^{47}$ International Convention for the Protection of All Persons from Enforced Disappearance, UN Doc A/61/488

(20 December 2006), art 2. Convention Against Torture art 1(1).

${ }^{48}$ Teitel (n 19) 59.
} 
such distinctions in the wake of an inter-ethnic conflict can be problematic where the postconflict State may wish to grant amnesty to combatants who fought in ethically defined factions, or where prosecutors may be under pressure to be 'even-handed' when designing their prosecution strategies. Similarly, where amnesties are designed to benefit offenders on the basis of political allegiances or opinions, which according to Teitel is a 'permissible categorical basis for clemency', the demands of equality may result in the scope of the amnesty being extended to ensure that it is 'bipartisan'. ${ }^{49}$ Teitel suggests that a bipartisan amnesty grant 'advances the rule of law and legitimacy in the exercise of clemency'. 50 However, where amnesty laws or prosecution strategies appear to treat all groups equally, it can also be problematic as such policies risk creating a 'myth of equivalency' where the actions of all parties are seen as equally justified. This is particularly delicate where one party to the conflict only committed a small proportion of the crimes, or had only resorted to violence in response to severe repression. This was a contentious issue before the South African Truth and Reconciliation Commission as the African National Congress protested the commission's findings on its culpability for human rights violations by arguing that that 'fighting for and against apartheid' were not equivalent. ${ }^{51}$ In general, where the State enacts a self-amnesty to benefit its own supports, this is likely to breach the principle of equality.

Finally, where amnesties are individualized and conditional, the equality principle can be a constraining factor in the amnesty granting process. For example, an individualised, conditional amnesty can result in perpetrators of similar crimes being treated differently depending on how they comply or are deemed to comply with the conditions. Under the equality principle, amnesty applicants should not be privileged or discriminated against on the grounds of race, religion or ethnicity. However, where the conditions for granting amnesty or prosecuting individual offenders are overly subjective, it can result in perpetrators of similar crimes being treated inconsistently, even where no discrimination is intended. ${ }^{52}$ This risks making the process appear arbitrary which could undermine its legitimacy. ${ }^{53}$ The risk of inequality can be lessened if the same conditions are applied uniformly to all individuals' applications, regardless of identity or former affiliation. In addition, where amnesties are coupled with selection prosecutions, the criteria used to determine who should face trial, or who can be amnestied, such 'reflect appropriate distinctions based upon degrees of culpability'. ${ }^{54}$ Orentlicher notes that such distinctions are 'drawn in every country's criminal law', through sentencing patterns. ${ }^{55}$

From the above, it is clear that post-conflict States are required to consider the principle of equality during the design and implementation of amnesties or limited prosecution strategies. In doing so, they may need to take into account inherent differences in the legal status of combatants, and the delicacies of balancing non-discrimination requirements with the need to address all communities who were harmed or implicated in the violence. In designing the amnesty or justice process, it seems likely that measures targeted

\footnotetext{
49 ibid 59.

50 ibid 59.

${ }^{51}$ J Sarkin, Carrots and Sticks: The TRC and the South African Amnesty Process (Intersentia, Antwerp, 2004) 111.

${ }^{52}$ For a discussion of the difficulties at the South African TRC in determining whether a crime was 'political', see RC Slye, 'Justice and Amnesty' in Charles Villa-Vicencio and Wilhelm Verwoerd (eds), Looking Back, Reaching Forward: Reflections on the Truth and Reconciliation Commission of South Africa (Zed Books, London 2000) 181-182.

${ }^{53}$ DF Orentlicher, 'Settling Accounts: The Duty to Prosecute Human Rights Violations of a Prior Regime' (1991) 100(8) Yale L J 2537, 2602.

54 ibid 2602-2603.

55 ibid.
} 
only at one group of offenders, such as self-amnesties for supporters of the government, are likely to violate the principle of equality. Finally, the principle of equality requires that where decisions to prosecute or grant amnesty are individualised, they should be based on clear, transparent and non-discriminatory criteria.

\section{AMNESTIES UNDER INTERNATIONAL LAW: EXPLORING THE 'GREY AREAS' IN THE DUTY TO PROSECUTE}

Although international policymakers, scholars, jurists and human rights campaigners increasingly proclaim that international law does not permit amnesty laws for serious crimes ${ }^{56}$ to date, no international convention has explicitly prohibited amnesty laws. ${ }^{57}$ Indeed, 'on every occasion where an explicit amnesty prohibition or discouragement has been mooted in the context of a multilateral treaty negotiation, states have demonstrated a resolute unwillingness to agree to even the mildest discouragement' ${ }^{58}$ As a result, discerning whether an amnesty law violates international law is a complex task. Firstly, it requires engagement with three distinct legal regimes: international humanitarian law, international human rights law and international criminal law. ${ }^{59}$ As none of these regimes contains a 'positive articulation' of a prohibition of amnesties, this must instead 'be "read into" a unified narrative of what the differentiated regimes collectively require'. ${ }^{60}$ This unified approach is also required as although international criminal law has developed considerably in the past two decades, it remains 'a legal environment resembling more a patchwork than a coherent, let alone complete, system', particularly since it covers only a limited number of crimes. ${ }^{61}$ To address these gaps in international criminal law, international human rights law is increasingly being relied upon to require States to prosecute serious crimes. ${ }^{62}$ According to Seibert-Fohr 'efforts have been made to refer to this body of law in order not only to interpret existing crimes but also to extend the catalogue of international crimes'. ${ }^{63}$ According to Bell, this process of 'regime merge' began in the 1990s in response to 'proposed and actual peace agreement amnesties'. ${ }^{64}$ As a result of this process, declarations made today on prohibitions of amnesties for serious human rights violations are derived 'holistically' from these diverse legal regimes. However, Bell argues that

regime merge involved seeing an overall import of the regimes as consolidating a 'tendency' or a 'direction' towards accountability that nonetheless did not require systematic and complete accountability for all crimes committed during the conflict. ${ }^{65}$

As this section will explore, the resulting position remains somewhat ambiguous but can be interpreted as accepting a role for both amnesty and criminal accountability in post-conflict transitional justice strategies. ${ }^{66}$

\footnotetext{
${ }^{56}$ Bell (n 29) 249.

${ }^{57}$ RC Slye, 'The Legitimacy of Amnesties Under International Law and General Principles of Anglo-American Law: Is a Legitimate Amnesty Possible?' (2002) 43 Va J Int'l L 1, 173179.

${ }^{58}$ Freeman (n 14) 33.

${ }^{59}$ Bell (n 29) 243.

60 ibid 249.

${ }^{61}$ SR Ratner, 'The Schizophrenias of International Criminal Law' (1998) 33 Tex Int'l L J 237, 250.

${ }^{62}$ A Seibert-Fohr, Prosecuting Serious Human Rights Violations (OUP, Oxford 2009) 3.

63 ibid 3.

${ }^{64}$ Bell (n 29) 243.

65 ibid 243.

66 ibid 250.
} 
Secondly, the exact relationship of an amnesty law to international law is always context specific. For example, it may depend upon the nature of the crimes being amnestied as taking part in hostilities may be a crime under domestic law, but it is not an international crime that requires prosecution. ${ }^{67}$ In addition, it may depend of the intensity and nature of the conflict because, as will be explored below, failures to prosecute may not violate international humanitarian law for all forms of conflict. Similarly, amnesties for political prisoners or refugees may actually be supported by international law. ${ }^{68}$ Furthermore, whether an amnesty breaches international law will depend on the post-conflict States' treaty commitments, including 'any valid reservations or interpretive declarations it may have made', as well as its obligations under customary international law. ${ }^{69}$ Ultimately, 'there is the possibility that the same conduct may be internationally wrongful so far as one state is concerned but not for another state having regard to its own international obligations'. ${ }^{70}$

Finally, within each of the legal regimes the status of amnesty laws is still evolving. This process is gradually shaping both the legal regimes themselves and the nature of contemporary amnesty laws. ${ }^{71}$ This section will outline the contemporary scope of the duty to prosecute under international in law in relation to three categories of crimes: international crimes, transnational crimes and serious human rights violations.

\section{A. International Crimes}

Firstly, and most clearly, the duty to prosecute has been invoked in relation to international crimes. According to Cryer these crimes can be distinguished from transnational crimes or human rights violations as the 'locus of the criminal prosecution is the international legal order', ${ }^{72}$ rather than domestic law. Currently, there are three widely accepted international crimes: genocide, war crimes, and crimes against humanity. Even within this category of crimes there are arguably divergences in the nature of the duty to prosecute.

For international crimes that are proscribed by international conventions, namely genocide $^{73}$ and 'grave breaches' of the Geneva Conventions and Additional Protocol I to these conventions, relating to international armed conflicts, ${ }^{74}$ the duty to prosecute has been described as 'absolute' and as creating a mandatory duty on States to prosecute. ${ }^{75}$ This implies that an amnesty for such crimes would violate a State's obligations to prosecute. ${ }^{76}$

\footnotetext{
${ }^{67}$ L Doswald-Beck, 'International Crimes' in Vincent Chetail (ed), Post-Conflict Peacebuilding: A Lexicon (OUP, Oxford, 2009) 170.

${ }^{68}$ UNHCR, Legal Safety Issues in the Context of Voluntary Reparation, UN Doc EC/54/SC/CRP.12 (7 June 2004) para 12.

${ }^{69}$ Freeman (n 14) 70.

${ }^{70}$ Commentaries to the Draft Articles on State Responsibility, Yearbook of the International Law Commission, 2001, Vol. II (Part 2), UN Doc A/CN.4/SER.A/2001/Add.1 at 65. Cited in Freeman (n 14) 70.

${ }^{71}$ Bell (n 29) 243.

${ }^{72}$ R Cryer, 'International Criminal Law' in MD Evans (ed), International Law (3rd edn, OUP,Oxford 2010) 753.

${ }^{73}$ Article I of the Genocide Convention provides 'The Contracting Parties confirm that genocide, whether committed in time of peace or in time of war, is a crime under international law which they undertake to prevent and punish'. Article IV provides 'Persons committing genocide or any other acts enumerated in Article III shall be punished, whether they are constitutionally responsible rules, public officials or private individuals'.

${ }^{74}$ Each of the four Geneva Conventions requires States parties to respond to 'grave breaches' by searching for, prosecuting and punishing perpetrators of grave breaches, unless they extradite them for purposes of trial by another State party. Additional Protocol I extends the same obligations to punish to a wide range of 'grave breaches'.

${ }^{75}$ See eg MP Scharf, 'The Letter of the Law: The Scope of the International Legal Obligation to Prosecute Human Rights Crimes' (1996) 59 Law \& Contemp Probs 4, 41.

${ }^{76}$ Freeman (n 14) 37.
} 
However, these conventions may not be applicable in many post-conflict settings due to the limitations in their scope. According to the definition of genocide in the Genocide Convention, this crime is restricted to actions taken with an 'intent to destroy, in whole or in part, a national, ethnical, racial or religious group'. ${ }^{77}$ This definition suggests two limitations. First, the requirement of 'specific intent literally to destroy a substantial portion of the population of a target group ${ }^{78}$ does not necessarily apply to many conflict situations. Secondly, the omission of acts directed against political groups, means that many situations of mass violence, such as South America's 'dirty wars', are not included in the scope of the Genocide Convention, and hence are excluded from its obligation to prosecute.

Similarly, the duty to prosecute under the Geneva Conventions and Additional Protocol I applies only to 'grave breaches' committed during international armed conflicts. However, since the end of the Second World War, international wars have been rare, and today the majority of contemporary wars are internal armed conflicts, for which there is no explicit duty to prosecute. Instead, as will be discussed below, Additional Protocol II to the Geneva Conventions, which establishes the international humanitarian law framework for non-international armed conflicts encourages States parties to enact 'the broadest possible amnesty' at the end of hostilities. ${ }^{79}$ This Protocol only applies to conflicts that 'take place in the territory of a High Contracting Party between its armed forces and dissident armed forces or other organized armed groups', where the rebels are 'under responsible command, exercise such control over a part of [the state's] territory as to enable them to carry out sustained and concerted military operations' ${ }^{80}$ It does not apply to 'situations of internal disturbances and tensions, such as riots, isolated and sporadic acts of violence'. ${ }^{81}$ As a result, the duty to prosecute war crimes committed in non-international armed conflicts, low-intensity conflicts, and crimes against humanity committed during conflicts or by repressive regimes, draws upon customary international law rather than international conventions. ${ }^{82}$

Although crimes against humanity and war crimes committed in internal conflicts are widely perceived as international offences and have sometimes been prosecuted before national and international courts, this does not automatically imply the existence of a mandatory duty to prosecute. ${ }^{83}$ Article 38 of the International Court of Justice (ICJ) Statute requires that determinations of whether such a duty exists under customary international law must be based on State practice and opinio juris. This can include consideration of the existence or absence of relevant domestic legislation (either granting amnesties or requiring prosecutions); State practice in relation to mediating peace agreements that include or exclude amnesty provisions or to financially and diplomatically support amnesty processes; State willingness to include provisions prohibiting amnesty in international conventions; voting patterns in UN General Assembly resolutions; or judgements of domestic courts. The ICJ Statute also provides that judicial decisions and academic research can be 'subsidiary' sources of international custom. At present, some subsidiary sources strongly support the existence of the duty to prosecute crimes against humanity and serious violations committed in non-international armed conflicts. However, State practice appears much less supportive of such a duty.

\footnotetext{
${ }^{77}$ Genocide Convention, art 2.

${ }^{78}$ Scharf (n 75) 45.

${ }^{79}$ Protocol Additional to the Geneva Conventions of 12 August 1949, and relating to the Protection of Victims of Non-International Armed Conflicts (Protocol II), 8 June 1977, Art 6(5).

${ }^{80}$ ibid, art 1(1).

${ }^{81}$ ibid, art 1(2).

${ }^{82}$ Cryer (n 72) 778.

${ }^{83}$ A O'Shea, Amnesty for Crime in International Law and Practice (Kluwer Law International, The Hague, 2002) 205.
} 
Firstly, in relation to the enactment of amnesty laws, State practice has yet to be systematically reviewed. Perhaps the closest effort to do this is the Amnesty Law Database created by the author, which collates detailed information on amnesty laws enacted around the world since the end of the Second World War, including whether the amnesty included or excluded crimes under international law (defined as genocide, crimes against humanity, war crimes, torture or enforced disappearances). However, this broad survey encompassing over 520 amnesty laws enacted in 138 countries between 1945 and 2010 has some limitations in relation to identifying State practice. Firstly, although the State's treaty ratifications at the time of the amnesties' enactment are considered, the existence of relevant declarations or reservations is not. Secondly, identifying whether international crimes were committed can be problematic where States seek for political reasons to obfuscate the nature of crimes being amnestied by framing them as violations of domestic criminal law, rather than characterizing them as crimes under international law (for example, granting amnesty for murder or rape, rather than crimes against humanity), or by declining to list the crimes that are amnestied, preferring instead to grant amnesty to all political or conflict-related offences committed within prescribed dates. Similarly, where a conflict has had considerable international dimensions, discerning whether it was an international or internal armed conflict at the time the amnestied crimes were committed can be a highly politicised issue.

Addressing these problems systematically would entail context-specific analyses that are beyond the scope of the Amnesty Law Database project in its current form. Instead, in constructing the Amnesty Law Database, the author has taken a cautious approach and entered data relating to international crimes only when (1) the crimes were explicitly mentioned in the text of the amnesty; (2) when case law indicated that the amnesty included or excluded crimes under international law; and/or (3) when there is substantial evidence in reports by UN or regional human rights institutions or by respected human rights organisations, such as Amnesty International or Human Rights Watch, that crimes under international law were perpetrated. As a result, it is probable that the Amnesty Law Database under-represents the number of amnesty processes which grant impunity for crimes under international law. Nonetheless, from the data that has been compiled to date it is apparent that over the past thirty years, the rate of amnesties including crimes under international law has increased, but since the early 1990s, a growing number of amnesties have excluded crimes under international law. However, after a peak around 1999, the number of amnesties explicitly excluding crimes under international law has fallen, and since the mid-2000s, roughly similar numbers of amnesty laws both include and exclude international crimes. ${ }^{84}$

Secondly, as part of the continued enactment of amnesty laws around the world, some States have continued to show themselves to be willing to support peace negotiations in which amnesties are agreed. ${ }^{85}$ Although as noted above, the UN changed its position on amnesties in conflict mediation at the signing of the Lomé Accord in 1999, there continue to be numerous examples, where States and international organizations have supported negotiations and peace agreements which offered amnesties to combatants. For example, during the final stages of the conflict between the Tamil Tigers and the Sri Lankan government in 2009, international actors, including the European Parliament, vocally

\footnotetext{
${ }^{84}$ L Mallinder, Amnesty, Human Rights and Political Transitions: Bridging the Peace and Justice Divide (Studies in International Law, Hart Publishing, Oxford 2008); L Mallinder, 'Cross-National Perspectives on Amnesty Laws', Paper prepared for Amnesty in the Age of Accountability: Brazil in Comparative and International Perspective conference, University of Oxford, 22-23 October 2010 (on file with the author).

${ }^{85}$ As noted above, no systematic effort to review State practice in this area exists, but initial analysis is available in L Mallinder, Amnesty, Human Rights and Political Transitions, ch 8.
} 
endorsed an amnesty for surrendering insurgents. ${ }^{86}$ These statements of support made no reference to the need to prosecute serious human rights violations that had been committed during the conflict. In addition to statements of support, some amnesty processes receive financial backing. For example, the Ugandan Amnesty Act 2000, which granted amnesty for all conflict-related crimes committed by insurgents fighting against the government, including the atrocities committed by the Lord's Resistance Army, has consistently received financial support from international donors for its implementation. Most recently, in January 2008, the Ugandan Amnesty Commission received funding of US\$10,055,278 from a World Bank Multi-Donor Trust Fund to support its work. The donors to this fund included Sate parties to the International Criminal Court (ICC) such as Denmark, Norway, the Netherlands, Sweden and the UK. ${ }^{87}$ These endorsements of amnesties for serious crimes appear not to have been motivated by a desire for impunity, but rather recognition of the role that amnesty can play in encouraging combatants to surrender and disarm. Although as yet, no study has systemically documented State practice in endorsing or supporting amnesties in third States, according to Trumbull, anecdotal evidence suggests that 'even states that are not affected by the crimes do not recognize any law that prohibits affected states from granting amnesty'. ${ }^{88}$

Thirdly, States have consistently failed to prohibit amnesty laws in international conventions. For example, during the Rome Conference delegates debated a range of proposals relating to amnesty laws, but were ultimately unable to reach a consensus on prohibiting them in the ICC Statute. As a result, the Statute contains no reference to amnesty legislation. ${ }^{89}$ Indeed, to date, the only convention to discuss amnesty laws explicitly is Additional Protocol II to the Geneva Conventions, which as noted above, encourages States parties to enact the 'broadest possible amnesty to persons who have participated' in noninternational armed conflicts. ${ }^{90}$ The Commentary on the Additional Protocol asserts that this provision is 'to encourage gestures of reconciliation which can contribute to re-establishing normal relations in the life of a nation which has been divided'. ${ }^{91}$ According to the International Committee of the Red Cross (ICRC), this amnesty should only cover 'combat immunity', which would ensure that a combatant cannot be punished simply for participating in the conflict, 'including killing enemy combatants, as long as he respected international humanitarian law, ${ }^{92}$ This means that, where war crimes were committed, for example, by a failure to apply the minimum standards of common article 3 of the Geneva Conventions, the ICRC argues it was still intended that the perpetrators would be prosecuted, and that an amnesty law would not cover such crimes even during an internal conflict. In its 2005 study of customary international humanitarian law, the ICRC argued that its interpretation of article

\footnotetext{
${ }^{86}$ Eg 'Co-Chairs Of Sri Lanka Peace Process Urge Tamil Tigers To End Hostilities', RTT News (3 Feb 2009); 'Lay down arms, surrender - European Parliament tells LTTE', The Colombo Times (6 February 2009); 'U.N. Security Council Asks LTTE To Surrender', RTT News (22 April 2009).

${ }^{87}$ World Bank, 'Project Information Document: Uganda Emergency Demobilization and Reintegration Project' (23 January 2008); _ 'World Bank offers over sh3 billion to resettle former ADF, LRA Rebels' New Vision (Kampala 19 August 2008).

${ }^{88}$ CP Trumbull, 'Giving Amnesties a Second Chance' (2007) 25 Berkeley J Int'l L 283295.

${ }^{89}$ WA Schabas, An Introduction to the International Criminal Court (3rd edn, CUP, Cambridge 2007$) 87$.

${ }^{90}$ Protocol Additional to the Geneva Conventions of 12 August 1949, and relating to the Protection of Victims of Non-International Armed Conflicts (Protocol II) 1977, Art 6(5).

${ }^{91}$ Y Sandoz, C Swinarski and B Zimmerman (eds), Commentary on the Additional Protocols of 8 June 1977 to the Geneva Conventions of 12 August 1949 (ICRC, Geneva 1987) para 4618.

${ }_{92} \mathrm{~T}$ Pfanner, Head of the ICRC Legal Division cited in D. Cassel, 'Lessons from the Americas: Guidelines for International Response to Amnesties for Atrocities' (1996) 59 Law and Contemporary Problems 197, 218.
} 
6(5) has become part of customary international law. However, the ICRC study considered only a few amnesty laws. ${ }^{93}$ Furthermore, Freeman argues that

under any approach it is hard to reconcile states' refusal to codify an explicit prohibition or discouragement of amnesties in the context of multilateral treaty negotiations with the purported existence of a custom-based amnesty prohibition. $^{94}$

In contrast to the statements of international and hybrid courts, the trends in State practice outlined above have encouraged several commentators to question the prohibition of amnesties under customary international law. For example, Cryer states 'there is not sufficient State practice yet to assert that customary law imposes a duty to prosecute all international crimes, and certainly not on the basis of universal jurisdiction'. 95 Similarly, Trumbull has argued that

although some countries and various international tribunals have declared that amnesties violate customary international law, the large number of amnesties granted in the last twenty years - and the participation of third party countries in brokering these deal-indicates that the state practice does not support this claim. $^{96}$

As a result, in relation to international crimes regulated by customary international law, namely crimes against humanity and war crimes in non-international armed conflicts, it appears that the best that can be argued at present is that the duty to prosecute is permissive, rather than mandatory.

\section{B. Transnational Crimes}

Transnational crimes have been described by Cryer as crimes that are prohibited by convention, but where the conventions 'do not, in themselves create direct liability international crimes'. ${ }^{97}$ Instead, they require State parties to criminalise the crime within domestic law. This makes the 'locus of the criminal prosecution ... the domestic, not the international legal order' ${ }^{98}$ In relation to post-conflict peacebuilding, the most relevant transnational crimes are torture and enforced disappearances, which are both subject to international conventions. However, these conventions contain limitations. Firstly, as noted above, in their definitions of the crimes, both conventions state that the offence can only be committed 'by or at the instigation of or with the consent or acquiescence of a public official

\footnotetext{
93 JM Henckaerts and L Doswald-Beck (eds), Customary International Humanitarian Law, Vol 1: Rules, (CUP, Cambridge, 2005) rule 159. Volume Two of this study looks at 'Practice' and discusses six treaties (Additional Protocol II, plus five peace treaties), which provide for amnesty; and 17 amnesty laws from 11 States. In addition, it looks to other sources of practice including national legal provisions governing the grant of amnesty, military manuals, national and international case law and UN resolutions. However, in each case, the number of the sources employed is comparatively small.

${ }^{94}$ Freeman (n 14) 33.

${ }^{95}$ Cryer (n 72) 778

96 Trumbull (n 88) 291.

${ }^{97}$ Cryer (n 72) 753.

98 ibid 753. Cryer further States that 'It is sometimes thought that the question of whether torture is an international crime turns, at least in part, on whether the Torture Convention has achieved customary status. However, since the Convention itself does not create a direct criminal prohibition, it cannot form the basis of a customary prohibition of this type. If the Torture Convention is customary, then all States are obliged to prohibit torture domestically, not accept the existence of a direct criminal prohibition on torture in customary international law'.
} 
or other person acting in an official capacity'. ${ }^{99}$ This means that torture or enforced disappearances committed by non-state actors would not fall within the scope of these conventions.

Secondly, where a State official is accused of torture or enforced disappearances, the conventions require States parties to investigate the facts, ${ }^{100}$ and if appropriate, 'submit the case to its competent authorities for the purpose of prosecution' or extradite the suspect. ${ }^{101}$ They further state that domestic authorities shall decide whether to prosecute these offences in 'the same manner as in the case of any ordinary offence of a serious nature under the law of that State'. ${ }^{102}$ This wording is more ambiguous than the explicit obligations outlined in the Genocide Convention or the Geneva Conventions. Consequently, it has caused many commentators to argue that there is a degree of permissiveness regarding the manner in which a State must carry out its duties under these conventions, as they do 'not explicitly require a prosecution to take place, let alone that punishment be imposed and served'. ${ }^{103}$ It seems, instead, to leave the decision on whether to prosecute alleged torturers or persons responsible for disappearances to the discretion of the prosecutorial authorities.

Finally, the Convention on Enforced Disappearance allows States parties to establish 'mitigating circumstances' for persons

who, having been implicated in the commission of an enforced disappearance, who effectively contribute to bringing the disappeared person forward alive or make it possible to clarify cases of enforced disappearance or to identify the perpetrators of an enforced disappearance. ${ }^{104}$

According to McCrory, 'depending on the precise operation of national law', such mitigating circumstances can 'impact on the penalty imposed', by reducing or removing it. ${ }^{105}$ In this way, the convention provides for leniency for offenders who disclose truth about disappearances. Such disclosures could serve some of the objectives of prosecutions, such as uncovering the facts, attributing responsibility, providing some form of reparations and acknowledgement to victims, and communicating public repudiation of the crimes.

\section{Human Rights Law}

International and regional human rights conventions set out a wide range of human rights protections. However, only the most serious violations of these rights are argued to create a duty to investigate or prosecute perpetrators, and this duty is not explicitly mentioned in any of the conventions. Although no exact list of which human rights violations trigger these obligations exists, the UN has adopted the phrase 'gross violations of human rights' to describe these rights and it stipulates that this category includes 'torture and similar cruel,

\footnotetext{
${ }^{99}$ Convention Against Torture art 1(1). The Convention for the Protection of All Persons from Enforced Disappearance adopts similar wording to the Convention against Torture by restricting the application of the convention to 'agents of the State or ... persons or groups of persons acting with the authorization, support or acquiescence of the State'. International Convention for the Protection of All Persons from Enforced Disappearance, UN Doc. A/61/488 (20 December 2006), art 2.

${ }^{100}$ Convention Against Torture, art 6(2); International Convention for the Protection of All Persons from Enforced Disappearance, art 11

${ }^{101}$ Convention Against Torture, art 7(1).

102 Convention Against Torture, art 7(2); International Convention for the Protection of All Persons from Enforced Disappearance art 11.

${ }^{103}$ Orentlicher (n 53) 2604.

${ }^{104}$ Convention Against Torture, art 7(2).

${ }^{105}$ S McCrory, 'The International Convention for the Protection of all Persons from Enforced Disappearance' (2007) 7 Human Rights Law Review 545, 553.
} 
inhuman or degrading treatment; extra-judicial, summary or arbitrary executions; slavery; enforced disappearances; and rape and other forms of sexual violence of comparable gravity'. ${ }^{106}$ The UN has stated that it will not 'endorse provisions in peace agreements that include amnesties' for these violations. ${ }^{107}$ Where amnesties for serious violations have been challenged before the human rights treaty monitoring bodies the cases differ from the application of international criminal law, as the cases do not focus on prosecuting individual offenders. Instead, the human rights institutions are asked to consider whether by enacting amnesty legislation, a State has violated its international obligations, particularly the duties to provide a remedy, to investigate, to prosecute and punish, and to repair harm. ${ }^{108}$ This is possible even where the amnesty is valid under national law.

Several human rights treaty monitoring bodies have produced judgements and opinions on the extent to which amnesty laws have violated a State's obligations under their constituent treaties. However, due to limitations of space, the analysis of the decisions of these bodies will focus only the human rights institutions with binding jurisdiction that have issued judgements on this issue, namely the Inter-American Court of Human Rights and the European Court of Human Rights. ${ }^{109}$

Of these two institutions, the Inter-American Court has been more active in deciding whether amnesty laws violate the rights protected in the American Convention on Human Rights. The first amnesty decision to come before the Inter-American Court of Human Rights related to two amnesty laws enacted in Peru in 1995 under President Fujimori. ${ }^{110}$ These selfamnesty laws offered broad immunity to persons who had committed human rights violations on behalf of the State and their enactment prevented legal proceedings to investigate and prosecute massacres. This caused the Peruvian National Human Rights Coordinating Committee to bring the Barrios Altos case to the Inter-American system in $1995 .{ }^{111}$ The Inter-American Court issued its ruling in this case in 2001, in which it stated that with respect to the amnesty laws,

all amnesty provisions, provisions on prescription and the establishment of measures designed to eliminate responsibility are inadmissible, because they are intended to prevent the investigation and punishment of those responsible for serious human rights violations... ${ }^{112}$

As a result, the Court found that both Peruvian self-amnesty laws were manifestly incompatible with the American Convention on Human Rights and consequently, lacked

legal effect and may not continue to obstruct the investigation of the grounds on which this case is based or the identification and punishment of those

\footnotetext{
${ }^{106}$ UN Secretary-General, 'Guidance Note of the Secretary-General: United Nations Approach to Transitional Justice' (United Nations, March 2010) fn 8.

107 ibid 4.

${ }^{108}$ L Mallinder, 'Can Amnesties and International Justice be Reconciled?' (2007) 1 Int'1 J Transitional Just 2 , 208.

${ }^{109}$ For a discussion of the relevant jurisprudence of the UN's Human Rights Committee which issues opinions on individual complaints relating to violations of the International Covenant on Civil and Political Rights see Seibert-Fohr (n 62).

${ }^{110}$ Ley $\mathrm{N}^{\mathrm{0}} 26479$ Conceden amnistía general a personal militar, politica y civil para diversos casos (14 Jun 1995), published in Normas Legales, No. 229 (Jun 1995), oo. 200 ff. This was modified by Ley No 26492 Precisan interpretación y alcances de amnistía otogada por la Ley No 26479 (28 Jun 1995), published in Normas Legales, No. 230, Jun 1995, pp 8 ff.

${ }^{111}$ SA Canton, 'Amnesty Laws' in Katya Salazar and Thomas Antkowiak (eds), Victims Unsilenced: The InterAmerican Human Rights System and Transitional Justice in Latin America (Due Process of Law Foundation, Washington DC, 2007) 183.

${ }^{112}$ Barrios Altos Case (Chumbipuma Aguirre et al v Peru) (ser. C) No. 74 (2001), para 41.
} 
responsible, nor can they have the same or a similar impact with regard to other cases that have occurred in Peru, where the rights established in the American Convention have been violated. ${ }^{113}$

The Court then called on the State to 'investigate the facts to determine the identity of those responsible for the human rights violations referred to in this judgment, and also publish the results of this investigation and punish those responsible'. ${ }^{114}$ This was the first judgement in which an international court 'declared a national law invalid'. ${ }^{115}$

The second case relating to amnesty laws to come before the Inter-American Court was Almonacid-Arellano $v$ Chile. This case concerned the 1973 extrajudicial execution of Luis Almonacid-Arellano, which could not be investigated in Chile due to the 1978 amnesty law. ${ }^{116}$ The plaintiffs then took their case to the Inter-American Court of Human Rights, where their complaints focused on the denial of justice after 1990, when Chile accepted the Court's jurisdiction. In its judgement, the Court surveyed developments in international criminal law since the early 1990s, such as the jurisprudence of the ad hoc and hybrid tribunals and it determined that

The States cannot neglect their duty to investigate, identify, and punish those persons responsible for crimes against humanity by enforcing amnesty laws or any other similar domestic provisions. Consequently, crimes against humanity are crimes which cannot be susceptible of amnesty. ${ }^{117}$

The Court further argued that the continued application of the amnesty law after Chile had ratified the Convention and accepted the court's jurisdiction is 'overtly incompatible with the wording and the spirit of the American Convention, and undoubtedly affects the rights embodied in such Convention'. It found that 'this constitutes in and of itself a violation of the Convention and generates international liability for the State'. ${ }^{118}$ On this basis, the Court found that Chile's 1978 amnesty law

does not have any legal effects and cannot remain as an obstacle for the investigation of the facts inherent to the instant case, or for the identification and punishment of those responsible therefore. Neither can it have a like or similar impact regarding other cases of violations of rights protected by the American Convention which occurred in Chile. ${ }^{119}$

This finding mirrors the Court's ruling in the Barrios Altos case that Peru's amnesty laws were without legal effect. These findings were reiterated in 2010 Gomes Lund et al. ('Guerrilha do Araguaia') v Brazil, in which the Inter-American Court analysed the compatibility of Brazil's 1979 amnesty law ${ }^{120}$ with the American Convention on Human Rights. In this case, the Court

\footnotetext{
113 ibid para 44.

114 ibid.

${ }^{115}$ D Kuwali and J Pablo Pérez-León Acevedo, 'Smokescreens-A Survey of the Evolving Trends in Amnesty Laws in Africa and Latin America' (2008) 2 Malawi L J 115, 129-130.

${ }^{116}$ C Martin, 'Catching Up with the Past: Recent Decisions of the Inter-American Court of Human Rights Addressing Gross Human Rights Violations Perpetrated during the 1970s-1980s' (2007) 7 Hum Rts L Rev 4, 774, 777.

${ }^{117}$ Case of Almonacid-Arellano et al. v. Chile, I/A Court H.R., Preliminary Objections, Merits, Reparations and Costs. Judgment of September 26, 2006. Series C No. 154, para 114.

118 ibid, para 119.

119 ibid, para 119. See also para 145.

${ }^{120}$ Lei Concede anistia e dá outras providências 1979 Nº.683.
} 
concluded that the provisions of the Amnesty Law that prevent the investigation and punishment of serious human rights violations are incompatible with the American Convention and lack legal effect, and as such, cannot continue to represent an obstacle for the investigation of the facts of the case or for the identification and punishment of those responsible. ${ }^{121}$

More recently, in February 2011, the Inter-American Court in the Gelman v Uruguay case considered Uruguay's 1986 amnesty law which granted immunity for serious human rights violations committed by State officials. ${ }^{122}$ It found that even though official reinterpretations of this law from 2005 meant that it was no longer an obstacle to investigations and prosecutions in the present case, ${ }^{123}$ the State's failure to adapt its domestic law to confirm with the convention represented a violation of Article 2 of the Convention. ${ }^{124}$ The Court therefore held that 'the state must ensure that it never again be an obstacle to the investigation of the facts of the case or the identification and, if appropriate, punishment of those responsible for these and other grave human rights violations'. ${ }^{125}$

These judgements illustrate that the Inter-American Court has taken a strong position on both amnesties and the need to punish serious human rights violations. However, whilst clearly stating that self-amnesties prevent thorough investigations of the facts and punishment of the individuals responsible, thereby violating the American Convention, these judgments did not stipulate what form of punishment is appropriate. The court, however, provided clearer guidance in the 2007 judgment in the La Rochela Massacre case, where it discussed Colombia's Justice and Peace Law. ${ }^{126}$ In this judgment, the court found that a punishment or sanction must be proportional to the harm suffered. ${ }^{127}$ It referred to previous case law to explain that, for punishment to be proportional, it must address the harm suffered and the culpability with which the author acted. ${ }^{128}$ The court further added that the penalty must be 'issued by a judicial authority'. ${ }^{129}$ This formulation ties punishment to criminal proceedings. It does not address, however, whether all perpetrators must be subjected to prosecutions, or whether the State will be viewed as fulfilling its obligations if only those deemed most responsible for the policies of repression or individuals who committed the most notorious crimes are put on trial.

Unlike its Inter-American counterpart, the European Court of Human Rights has not any direct experience of dealing with amnesty laws. Furthermore, where it has been confronted with cases where serious human rights violations had been committed, the court has declined to proclaim an 'outright duty to punish'. Instead, it has found that States are under an obligation to conduct 'investigations capable of leading to the identification and punishment of those responsible'. ${ }^{130}$ The reference to prosecutions here seems to denote the quality of the investigations, rather than a requirement that prosecutions be conducted. With regards to amnesties, it indicates that where amnesty laws prevent investigations they would violate Article 2 of the European Convention on Human Rights. Amnesties that coexist with

\footnotetext{
${ }^{121}$ Inter-American Court of Human Rights, Press Release (14 December 2010) relating to Judgment in the Case of Gomes Lund et al. ('Guerrilha do Araguaia') v Brazil.

${ }^{122}$ Ley de Caducidad de la Pretensión Púnitiva del Estado, Ley No 15,848 (1986).

${ }^{123}$ Case of Gelman v. Uruguay, Inter-Am. Ct. H. R. (ser. C), No. 221 (2011), para 241.

124 ibid, para 246.

125 ibid, para 253.

${ }^{126}$ Ley de Justicia y Paz (2005).

${ }^{127}$ Case of the Rochela Massacre v Colombia (n 126) para 193.

${ }^{128}$ ibid para 196.

129 ibid para 196.

${ }^{130}$ This formulation has been used in numerous judgements by the ECtHR, see eg Aydin v Turkey (57/1996/676/866) 25 September 1997.
} 
or incentivize truth recovery may remain possible under this approach. However, the Court has cautioned that amnesty or impunity for State agents could undermine public confidence in the rule of law. ${ }^{131}$ For example, in the 2006 Abdülsamet Yaman $v$ Turkey case which involved allegations of article 3 violations concerning torture against a 12 -year old boy by the Turkish police, the Court stated in relation to a hypothetical amnesty that it

reaffirms that when an agent of the State is accused of crimes that violate Article 3, the criminal proceedings and sentencing must not be time-barred and the granting of an amnesty or pardon should not be permissible. ${ }^{132}$

This statement did not relate to a transitional context wherein amnesty was being considered as part of a broader process of national reconciliation. This distinction is significant because, as Seibert-Fohr notes, 'the call for criminal measures in ordinary cases should not be taken as evidence for an uncompromised formula which applies equally in exceptional circumstances'. ${ }^{133}$ However, given the court's strong statement on the duty to investigate, it seems likely that amnesties that prevent any form of truth-recovery would be in violation of the treaty provisions.

Overall, it seems that within international human rights law, the most strident opposition to national amnesty laws has come from the Inter-American Court of Human Rights. However, Cryer notes that 'it is by no means clear that this is reflective of a more general principle of human rights law, and probably has much to do with the particular context of Latin America', and the fact that the amnesty laws under consideration were selfamnesties granted by repressive regimes. ${ }^{134}$ Other human rights institutions, such as the UN's Human Rights Committee and the European Court of Human Rights 'have not gone so far as the Inter-American Court', which casts doubt on the extent to which a universal prohibition of amnesty laws has become part of international human rights law. ${ }^{135}$

\section{PREVENTING IMPUNITY}

Within transitional justice literature, prosecutions for serious human rights violations are often advocated on political as well as legal grounds. These arguments typically suggest that an absence of prosecutions will create or reinforce a climate of impunity, and thereby undermine the rule of law. ${ }^{136}$ Here, impunity is understood in accordance with the UN's Updated Set of Principles to Combat Impunity as 'the impossibility, de jure or de facto, of bringing the perpetrators of violations to account - whether in criminal, civil, administrative or disciplinary proceedings'. ${ }^{137}$ The principles continue that both judicial and non-judicial proceedings should lead to perpetrators of serious crimes under international law 'being accused, arrested, tried and, if found guilty, sentenced to appropriate penalties, and to making reparations to their victims'. ${ }^{138}$ Under this approach, holding perpetrators to account is viewed as synonymous with criminal trials, and failures by States to investigate violations

\footnotetext{
${ }^{131}$ See eg Abdïlsamet Yaman v. Turkey, no. 32446/96, § 55, 2 November 2004

${ }^{132}$ Application no. 48939/99, 30 November 2004.

${ }^{133}$ Seibert-Fohr (n 62).

${ }^{134}$ Cryer (n 72) 778-9.

135 ibid $778-779$.

${ }^{136}$ Teitel (n 19) 54.

${ }^{137}$ UNCHR, 'Updated Set of principles for the protection and promotion of human rights through action to combat impunity', Commission on Human Rights E/CN.4/2005/102/Add.1 (Commission on Human Rights, 8 February 2005) 6.

138 ibid 6.
} 
and to ensure that 'those suspected of criminal responsibility are prosecuted, tried and duly punished' by for example enacting amnesty laws are perceived as resulting in impunity. ${ }^{139}$

For anti-impunity campaigners, failing to prosecute serious human rights violations holds many dangers for post-conflict States. For example, where the laws are not enforced, it may 'vitiate the authority of law itself, sapping its power to deter proscribed conduct'. ${ }^{140}$ Under such circumstances, individuals may believe "that they can "get away" with violence'. ${ }^{141}$ This situation would arguably encourage former perpetrators to continue their behaviour or new offenders to engage in violent crimes in the post-conflict period. Furthermore, under a climate of impunity, cultures of violence and corruption may endure due to the absence of prosecutions to communicate the norms and values that repudiate past crimes. ${ }^{142}$ This might in turn 'undermine the establishment of democratic institutions' ${ }^{143}$ In contrast, it is argued that prosecutions for past crimes might 'may assuage the community's fears and provide a sense of stability and security for the new democratic regime'. ${ }^{144}$

While these goals are of course laudable, in many post-conflict States, there are reasons to doubt whether omitting amnesty from a peace deal will eliminate impunity. Indeed, as will be explored below, where thousands of individuals have been engaged in violence and criminality during conflict, post-conflict States frequently face an 'impunity gap' where the national legal system does not have the capacity to try all the perpetrators and may face political constraints to widespread trials. ${ }^{145}$ Furthermore, Fletcher and Weinstein argue that the focus on individual criminal responsibility for ordering and carrying out mass violence

leaves three categories of persons and groups largely untouched: (1) unindicted perpetrators including community members who directly or indirectly profited from the event; (2) states outside the area of conflict that may have contributed to the outbreak of violence by their acts or omissions; and, (3) the bystanders who did not actively participate in violence, but who also did not actively intervene to stop the horrors. ${ }^{146}$

Furthermore, Leebaw argues that the 'extraordinary, temporary' nature of transitional justice institutions 'places them in tension with core principles associated with rule of law'. ${ }^{147}$ She contends that this tension can arise where pragmatic compromises are made that "narrow the scope and efficiency of transitional justice'. ${ }^{148}$ Such compromises could entail limiting the temporal jurisdiction of international or hybrid courts to narrowly specified periods or a restricted number of crimes. Furthermore, where prosecutions are carried out, 'lenient sentences, plea bargaining, and the refusal or inability to attain custody of key suspects can undermine' the courts' ability to communicate the rule of law to the populace. ${ }^{149}$ However, of

\footnotetext{
139 ibid Principles 1 and 24.

${ }^{140}$ Orentlicher (n 53) 2542.

${ }^{141}$ Chrissie Steenkamp, 'The Legacy of War: Conceptualizing a 'Culture of Violence' to Explain Violence after Peace Accords' (2005) 94(379) Round Table 253, 259.

${ }^{142}$ Bronwyn Anne Leebaw, 'The Irreconcilable Goals of Transitional Justice' (2008) 30 Hum Rts Q 95, 111.

143 Trumbull (n 88) 308.

144 ibid 308

${ }^{145}$ Paul van Zyl, 'Promoting Transitional Justice in Post-Conflict Societies' in Alan Bryden and Heiner Hänggi (eds), Security Governance in Post-Conflict Peacebuilding (Yearbook 3, Geneva Center for the Democratic Control of Armed Forces, Geneva 2005) 211-212.

${ }^{146}$ Laurel E. Fletcher and Harvey M. Weinstein, 'Violence and Social Repair: Rethinking the Contribution of Justice to Reconciliation' (2002) 24(3) Hum Rts Q 573, 579.

${ }^{147}$ Leebaw (n 142) 111.

148 ibid 111.

149 ibid 111.
} 
course, making such compromises may be an unavoidable outcome of the post-conflict situation. Where amnesties are granted as part of a political compromise, their impact on impunity may vary depending on the scope and effects of the law, and the relationship of the amnesty to trials or other accountability mechanisms.

\section{A. Limited Prosecutions and Limited Amnesties}

As noted above, amnesty laws can be designed to complement criminal justice strategies in diverse ways. Where enacted, such amnesties shield some specified offences, or offenders from prosecution, but would permit other prosecutions to proceed. Although this foreclosing of the possibility of prosecutions for some crimes might be seen as breach of the duty to prosecute, in fact it seems highly unlikely that international or domestic law would require post-conflict States to prosecute all offences. Indeed, as Teitel notes 'even in ordinary times, the rule of law is not predicated on fully enforced criminal justice, and the reasons for forbearance are often, as in transitional times, political'. ${ }^{150}$ Although there are differences between common law and civil law systems in the extent to which the principle of legality anticipates the law to be enforced, under both systems, many crimes will never be prosecuted. ${ }^{151}$ For example, McEvoy highlights that within the United Kingdom, only 'approximately 3-4 per of crimes result in a successful prosecution', a figure which he states is 'fairly typical for most advanced industrial societies'. ${ }^{152}$ Based on this he argues that 'even in the unlikely event' that the justice systems of post-conflict States could 'eventually be "raised" to the performance levels of their Western counterparts, they would still most likely fall far short of the mark'. ${ }^{153}$

Given the exceptional conditions faced by post-conflict States, it seems unlikely that they will be able to prosecute all past crimes, or even all ordinary crimes committed in the post-conflict period. As noted above, this was acknowledged by the UN Secretary-General in his report on Transitional Justice and the Rule of Law, ${ }^{154}$ in which he suggested that to address the 'impunity gap' prosecutors should develop prosecutorial policies that are 'strategic, based on clear criteria, and take account of the social context' and by introducing 'an effective communications strategy' to manage public expectations. ${ }^{155}$ A preference for selectivity in prosecutions has also been expressed by Orentlicher who argued that 'the demands of justice and political stability are best reconciled through a program of prosecutions that has defined limits'. ${ }^{156}$ To date, these prosecutorial strategies both at national and hybrid courts have generally focused on investigating and trying certain offences, such as those committed by the political and military elites, crimes under international law, or representative selections of crimes that will bring to light the patterns of victimisation that affected the different communities within the State.

The acceptance of amnesty laws as part of selective prosecution strategies has been described by Pensky as a 'sub-principle' of anti-impunity norm. ${ }^{157} \mathrm{He}$ argues that it recognizes that this norm has to be integrated into broader post-conflict peacebuilding

\footnotetext{
${ }^{150}$ Teitel (n 19) 55.

151 ibid 56.

${ }^{152}$ McEvoy (n 25) 436.

153 ibid 437.

${ }^{154}$ UNSC (n 21) para 46.

155 ibid para 46.

${ }^{156}$ Orentlicher (n 53) 2598-9.

${ }^{157}$ M Pensky, 'Amnesty on Trial: Impunity, Accountability, and the Norms of International Law' (2008) 1

Ethics \& Global Pol 1, 11-12.
} 
programmes that include disarmament, demobilisation and reintegration measures. ${ }^{158}$ Where amnesties coexist with prosecutions, rather than failing to bring those who are beyond at the scope of the limited prosecution strategy into a legal process, amnesties can facilitate their reintegration into society and law-abidance. Such amnesty laws could be limited to allow prosecutors to focus on investigating specific individuals, such as high-ranking military or political leaders, or members of armed factions who have not signed up to a peace agreement. Alternatively, amnesties laws could be limited by specifying that amnesty can only be granted for an explicit list of offences or that serious human rights violations are exempted from the amnesty. Furthermore, conditions could be attached to amnesty laws that would withdraw grants of amnesty for offenders who failed to engage fully with peacebuilding processes, by for example, refusing to participate in alternative accountability mechanisms or returning to violence. By reinstating the possibility of prosecution, such conditional amnesties could mirror the supposed deterrent effects of trials.

In this way, the amnesty laws could provide a 'filter' mechanism allowing prosecutors to direct their often limited resources towards prioritising offenders who are the least willing to be rehabilitated and reintegrated into society. Furthermore, although at first glance, amnesty laws seem to be antithesis of retributive justice as they are designed to shield offenders from legal punishments, they could arguably be designed to facilitate some prosecutions. For example, where amnesty or other leniency measures result in admissions of guilt or offenders testifying against their former superiors, they could contribute to the goals of retribution by speeding up complex trials and facilitating the gathering of evidence to prosecute those who are 'most responsible' or least repentant. Furthermore, by delivering exemplary prosecutions, rather than blanket amnesties, such combined processes can still 'vindicate the authority of the law' and communicate public norms to repudiate human rights violations. ${ }^{159}$ However, for this to be successfully achieved it is important that the prosecution strategy adhere to rule of law standards relating to the principle of equality and due process. It also essential that the limitations in the scope of the amnesty are not merely rhetorical, but that prosecutions where they remain possible are pursued.

\section{B. Amnesties as Delivering Accountability}

Although transitional justice literature frequently equates accountability with criminal prosecutions, the term is understood more broadly in other disciplines to encompass measures that require offenders to (1) answer for their crimes by outlining the facts and explaining or justifying their decisions, to have this testimony scrutinised and recorded; and (2) to submit to enforcement mechanisms. ${ }^{160}$ Although both answerability and enforcement are elements of criminal justice processes, in general, the punitive nature of trials may cause offenders to lie, obfuscate or conceal the full extent of their crimes. ${ }^{161}$ In this way, enforcement may be privileged over answerability.

In contrast, although amnesties impede some criminal enforcement mechanisms, recent amnesty laws in several jurisdictions have been designed to promote the answerability. For example, where amnesties are conditional on offenders disclosing and explaining their crimes in public hearings, such as before truth commissions or in restorative justice

\footnotetext{
158 ibid $11-12$.

${ }^{159}$ Orentlicher (n 53) 2598-2599.

${ }^{160}$ See L Mallinder and K McEvoy, 'Rethinking Amnesties: Atrocity, Accountability and Impunity in PostConflict Societies' (2011) 6 Contemporary Social Science 1, 107.

${ }^{161}$ S Cohen, 'Unspeakable Memories and Commensurable Law' in S Karstedt (ed), Legal Institutions and Collective Memories (Oñati International Series in Law and Society, Hart Publishing, Oxford, 2009) 27.
} 
processes, this can be viewed as a form of enforcement as such public confessions can cause offenders to feel shame and can damage their public reputations. ${ }^{162}$ For example, in his consideration of the South African amnesty processes as an accountability mechanism, Slye argued that '[a]mnesty does not come cheap' for the perpetrators as they face considerable public, personal and professional repercussions, and that ' $[\mathrm{p}]$ ublic shame, personal alienation and familial rejection should not be dismissed as insignificant'. ${ }^{163}$ Alternatively, amnesties can enforce accountability by encouraging compliance with vetting programmes that remove specific individuals from public office, particularly from the police or armed forces. Vetting can deliver enforcement through loss of status, loss of livelihood and in some cases loss of pension or other financial benefits. ${ }^{164}$ In other instances, leniency from prosecution has been incumbent of offenders contributing materially or symbolically to reparations programmes. According to Trumbull, incorporating accountability measures into an amnesty can send 'the message that the country condemns the acts, even if it does not prosecute'. ${ }^{165}$

Where amnesty laws are individualised and conditioned upon offenders participating in transitional justice and peacebuilding processes, they can help to serve some of the goals of these processes, plus also delivering some of the rationales of punishment. Where accountable forms of amnesty are coupled with trials, they can work to bring those who were previously outside the law into the new transitional constitutional framework and discourses on national reconciliation. In this way, amnesty laws can be viewed not as an end unto themselves, but rather as a bridging mechanism that can facilitate other goals of transitional justice projects and prevent impunity developing.

\section{CONCLUSION AND RECOMMENDATIONS}

In keeping with the ATLAS project objectives, this section will offer recommendations on how the European Union (EU) should approach amnesty laws in order to promote human rights and international humanitarian law after armed conflicts. To date, although the EU institutions have acknowledged a role for transitional justice and the rule of law programmes, ${ }^{166}$ and have made funding available to support such initiatives, ${ }^{167}$ they have yet to develop a central statement of EU policy for all three of the core international crimes: genocide, war crimes and crimes against humanity. ${ }^{168}$ Furthermore, the practice of EU

\footnotetext{
${ }^{162}$ See eg J Braithwaite, Crime, Shame, and Reintegration (CUP, Cambridge 1999).

${ }^{163}$ Slye (n 57) 6-7.

${ }^{164}$ See eg Alexander Mayer-Rieckh and Pablo de Greiff (eds), Justice as Prevention: Vetting Public Employees in Transitional Societies (Social Science Research Council, New York, 2007).

165 Trumbull (n 88) 313-314.

${ }^{166}$ Communication from the Commission to the Council, the European Parliament, the European Economic and Social Committee and the Committee of the Regions, 'Towards an EU response to situations of fragility: engaging in difficult environments for sustainable development, stability and peace' COM(2007) 643 final (Commission Of The European Communities, Brussels, 2007) 9.

${ }^{167}$ European Commission supports additional assistance for reconciliation of societies affected by human rights abuses, IP/08/1057, Brussels, 1 July 2008. The European Commission has also established a Peace-building Partnership 'to develop the capacity of its potential partners to respond to crisis situations worldwide'. For more information, see European Union External Action, 'Peace-building Partnership', available online at http://www.eeas.europa.eu/ifs/pbp_en.htm (accessed 9 February 2011).

${ }^{168}$ L Davies, 'The European Union, Transitional Justice and Peace Mediation' (Initiative for Peacebuilding, July 2010) 11. However, the European Union Guidelines on promoting compliance with international humanitarian law (IHL) state that 'Individuals bear personal responsibility for war crimes. States must, in accordance with their national law, ensure that alleged perpetrators are brought before their own domestic courts or handed over for trial by the courts of another State or by an international criminal tribunal, such as the International Criminal Court'. See Official Journal of the European Union, (2005/C 327/04) 23 December 2005, 14. This was restated in Updated European Union Guidelines on promoting compliance with international humanitarian law, Official Journal of the European Union, (2009/C 303/06) 15 December 2009, 14.
} 
institutions and Member States towards amnesties within peacebuilding programmes is inconsistent. ${ }^{169}$ For example, although all EU Member States have ratified the Rome Statute of the ICC, several Member States have been willing to contribute financially to the work of the Ugandan Amnesty Commission despite the ICC arrest warrants issued for the leaders of the Lord's Resistance Army. Furthermore, the EU is financially supporting the Justice and Peace Law in Colombia under which right-wing paramilitaries are being disarmed, ${ }^{170}$ and through its role in the Aceh Monitoring Mission, the EU monitored the reintegration of amnestied former combatants and ruled on disputed amnesty cases. ${ }^{171}$ In both Colombia and Aceh, serious human rights violators were able to benefit from leniency in relation to legal sanctions. Furthermore, as noted above, during the final stages of the conflict between the Tamil Tigers and the Sri Lankan government in 2009, international actors, including the European Parliament, vocally endorsed an amnesty for surrendering insurgents. ${ }^{172}$ These statements of support made no reference to the need to prosecute serious human rights violations that had been committed during the conflict. Finally, several EU Member States have amnesty legislation that prevents prosecutions into human rights violations committed in the past, for example, the amnesty laws enacted in Spain in the 1970s following the death of General Franco, and the series of amnesties enacted in France following the Evian Accords which granted independence to Algeria.

The inconsistent approach of the EU institutions and Member States seems in keeping with the unsettled status of amnesties under international law as outlined above, namely that international law requires some accountability for serious human rights violations, but still acknowledges a role for amnesties to encourage combatants to participate in peacebuilding measures. Consequently, the challenge for the EU in developing a coherent approach to amnesty laws is to balance the need for amnesty with efforts to promote the rule of law and hold serious offenders accountable for their crimes. Based on the arguments outlined in this paper and the experiences of amnesty laws to date, the author notes that amnesties can play a positive role in conflict transformation, and therefore recommends that the EU should not pursue an automatic prohibition of amnesties. However, neither should it support automatic, unconditional amnesties or self-amnesties enacted by repressive regimes. Instead, the EU should support amnesties only where they are necessary components of broader peacebuilding projects and where they meet certain conditions. These conditions can include requirements that amnesties be part of wider reform measures, such as measures to introduce democratic rule, promote reconciliation and promote stability in the post-conflict State by encouraging combatants to surrender. Furthermore, amnesties should not represent impunity, but rather should be designed to complement prosecution strategies or non-judicial accountability mechanisms, such as truth commissions, restorative justice processes, vetting and reparations programmes. In addition, where amnesty laws are adopted, they must confirm to domestic rule of law requirements, particularly the principle of equality and procedural rules on amnesty enactment, and as far as possible, deliberations on amnesty legislation

\footnotetext{
${ }^{169}$ However, the EU Guidelines on Children and Armed Conflict state 'Making use of the various tools at its disposal, the EU will seek to ensure that specific needs of children will be taken into account in early-warning and preventive approaches as well as actual conflict situations, peace negotiations, peace agreements, ensuring that crimes committed against children be excluded from all amnesties, post-conflict phases of reconstruction, rehabilitation, reintegration and long-term development'.

${ }^{170} \mathrm{~T}$ Unger, 'The European Union and Transitional Justice' in S Blockmans, J Wouters and T Ruys (eds), The European Union and Peacebuilding: Policy and Legal Aspects (TMC Asser Press, The Hague 2010).

${ }^{171}$ Aceh Monitoring Mission, 'Amnesty, Reintegration and Human Rights' available online at http://www.acehmm.org/english/headquarter_menu/amnesty.htm (accessed 11 February 2011).

${ }^{172}$ Eg 'Co-Chairs Of Sri Lanka Peace Process Urge Tamil Tigers To End Hostilities', RTT News (3 Feb 2009); 'Lay down arms, surrender - European Parliament tells LTTE', The Colombo Times (6 Feb 2009); 'U.N. Security Council Asks LTTE To Surrender', RTT News (22 Apr 2009).
} 
should be public and participative. Where amnesties adhere to these requirements, the EU should work to make them more effective by providing financial resources to amnesty and DDR programmes; supporting the training and empowerment local civil society groups to sensitise local communities and facilitate the reintegration of combatants; and where amnesties are designed to complement prosecution strategies, supporting the rule of law reforms that are required to ensure that prosecutions can take place. 